Article

\title{
Football for Inclusion: Examining the Pedagogic Rationalities and the Technologies of Solidarity of a Sports-Based Intervention in Sweden
}

\author{
David Ekholm * and Magnus Dahlstedt \\ Department of Social and Welfare Studies, Linköping University, 58183 Linköping, Sweden; E-Mails: david.ekholm@liu.se \\ (D.E.), magnus.dahlstedt@liu.se (M.D.)
}

* Corresponding author

Submitted: 12 December 2016 | Accepted: 6 April 2017 | Published: 29 June 2017

\begin{abstract}
Sports practices have been emphasised in social policy as a means of responding to social problems. In this article we analyse a sports-based social intervention performed in a "socially vulnerable" area in Sweden. We examine the formation of includable citizens in this project, based on interviews with representatives involved in the project. The material is analysed from a governmentality perspective, focusing on how problems and solutions are constructed as being constitutive of each other. The focus of the analysis is on social solidarity and inclusion as contemporary challenges, and how sport, specifically football, is highlighted as a way of creating social solidarity through a pedagogic rationality-football as a means of fostering citizens according to specific ideals of solidarity and inclusion. The formation of solidarity appears not as a mutual process whereby an integrated social collective is created, but rather as a process whereby those affected by exclusion are given the opportunity to individually adapt to a set of Swedish norms, and to linguistic and cultural skills, as a means of reaching the "inside". Inclusion seems to be possible as long as the "excluded" adapt to the "inside", which is made possible by the sports-based pedagogy. In conclusion, social problems and social tensions are spatially located in "the Area" of "the City", whose social policy, of which this sports-based intervention is a part, maintains rather than reforms the social order that creates these very tensions.
\end{abstract}

\section{Keywords}

football; pedagogy; segregation; social inclusion; solidarity; sport

Issue

This article is part of the issue "Sport for Social Inclusion: Questioning Policy, Practice and Research", edited by Reinhard Haudenhuyse (Vrije Universiteit Brussel, Belgium).

(C) 2017 by the authors; licensee Cogitatio (Lisbon, Portugal). This article is licensed under a Creative Commons Attribution 4.0 International License (CC BY).

\section{Introduction}

At the forefront of the ongoing political debate are the challenges created due to an increase in segregation. Inequality, alienation, and exclusion are some of the concepts used to describe the tensions and conflicts arising, and in turn threatening, community and social cohesion. This debate highlights the role of welfare state interventions when it comes to taking action against conflict, tensions, and social problems-the problem of solidarity.

In recent decades, there has been a broad repertoire of innovative strategies and activities emerging to com- bat these problems. For example, civil society has been highlighted as an arena with great potential for creating inclusion (Dahlstedt \& Hertzberg, 2011). One example of the mobilisation of civil society is the mobilisation of sport as an arena to meet a variety of social problems (Ekholm, 2017a). Seemingly new strategies to meet the challenges emerging from social policy address a classic question of the theory and practice of the welfare state: how can conflicts be counteracted and social solidarity created? In turn, this question follows on from the pedagogic rationality of such interventions (Philp, 1979), i.e., how the creation of solidarity is based on the notion of inclusion and the fostering of includable citizens. 
In this article, we focus on social solidarity as a contemporary challenge, and how sport, specifically football, is highlighted as a way of creating social solidarity. We will look at a sports-based social intervention, primarily focusing on fostering children into good citizens: Football for Inclusion (the Activity), performed in a "socially vulnerable" area (the Area), in a Swedish city (the City). The aim of the article is to analyse (1) how the problems this intervention is intended to address are constructed, (2) how social solidarity is formed as a solution to these problems, and (3) how and with which ideals the targeted individuals and families are made includable, i.e., how they are fostered according to certain norms of social inclusion and participation.

Football for Inclusion was started in 2014 by two football associations, with the objective of "using organised football to improve young people's social and language skills and work towards inclusion in Swedish society". The aim of the Activity is also to "get children and young people to get active during their leisure time", to create "an understanding of rules and types of work", and to "stimulate friendship between young people from different cultures". The sports activities, consisting of organised football, are aimed at school children in one of the City's most socially and economically vulnerable areas, with a high proportion of inhabitants from migrant backgrounds. Approximately 200 school children aged 8-12 years old participated in the activities during and after school hours. The activities were led on-site by four sports-leaders (described here as the Organiser, the Sports leader, Sports coach 1, and Sports coach 2). Football for Inclusion is run as a community-based programme by local sports and football associations in collaboration with schools and recreation centres, and is financed by a range of public, private, and civil society actors in partnership. The Activity is designed as a sportsbased intervention using sport as a vehicle to promote social inclusion. In this sense, Football for Inclusion is neither a football club nor is it affiliated with the local football federation (although, for instance, the Initiator is a representative of the managing association's board of directors).

\section{Analytical Perspective}

The analysis is inspired by a governmentality approach that focuses on the relation between problem and solution (Bacchi, 2009; Foucault, 2004), and particularly by Donzelot's $(1979,1988,1991)$ approach to problems and solutions which identifies the welfare state as a means of creating social solidarity. We analyse the tensions and conflicts that are articulated, and the boundaries and lines of conflict that are created through a specific intervention-football as a means of inclusion. It is this particular interweaving of problem and solution that Donzelot $(1988,1991)$ takes as his starting point in analysing the genealogy and tasks of the welfare state, where the focus is on technologies of solidarity.
According to Donzelot (1991), it was through the emergence of the welfare state in the early 1900s that social fragmentation, tensions, and conflicts arising from capitalism could be met with interventions of social solidarity. The provision of welfare aimed at producing solidarity between individuals and classes, thus constituting an alternative to the social mindsets dominating the late 1800 s of liberalism (competition between free individuals) and Marxism (class struggle). Accordingly, the ambition was "breaking down antagonistic attitudes, it aims at the gradual realisation of a consensus society" (Donzelot, 1991, p. 174). Here, the lines of conflict threatening solidarity, drawn primarily on the basis of socioeconomic conditions, needed to be combated.

The welfare state could intervene by means of technologies of solidarity. Firstly, by technologies that guaranteed individuals collective insurance and protection against risks (technologies of insurance), and secondly, technologies that guaranteed social rights (technologies of rights). Here, interventions were made in people's everyday lives by protective legislation and productive services, aimed at compensating for the socio-economic inequalities produced by the capitalist economy (Donzelot, $1988,1991)$. These technologies aim at fostering individuals and establishing certain norms in the population, thus drawing boundaries between the normal and the deviant. The technologies further aim to change the deviant and in this way the social state can intervene in the lives of families and individuals (Donzelot, 1979). The technologies also aim at providing for the most vulnerable people in society, as vulnerability creates fragmentation and conflict. Together, the technologies give a particular meaning to "the social", as the collective form of solidarity. Governing from the social point of view, perhaps finds its clearest form in the Swedish, social-democratic welfare regime (Esping-Andersen, 1990). However, social policy based on state-centred insurance and risk protection, as well as publicly funded and publicly organised service provision, is currently transforming into more advanced liberal forms of governing welfare (Larsson, Letell, \& Thörn, 2012).

The problems in the social policy landscape of today in a way illustrate this problem of solidarity. The question is still how the welfare state can manage to create solidarity and how fostering the population according to certain norms can be arranged. From this point of view, it is possible to examine in more detail the creation of solidarity, the establishment of norms, and the fostering of includable citizens.

\section{Method and Material}

The analysis is based on interviews with the representatives and leaders of Football for Inclusion. In all, seven interviews were conducted and transcribed verbatim. The Initiator represents the boards of the participating associations. He has a substantial network of contacts in the municipality, not only among politicians and officials, but also 
in trade and industry. The Organiser is a qualified sports teacher with a broad experience of management assignments within the sports movement. He is responsible for developing an activity plan. The Sports leader has many years of experience in the sports movement, and is also a trained pre-school teacher. Sports coach 1, who describes herself as a "girl and immigrant who plays football and is studying to be a teacher", and Sports coach 2 both help to lead the sports activities. The Headmaster is responsible for contact and communication between the school and the sporting Activity. The Municipal representative is an official in the municipal administration and is responsible for the administration's contribution to the project. The interviews were based on the respondents' own descriptions of Football for Inclusion, its activities, and its strategic objectives. The interviews were led with the support of a thematic interview guide which had a focus on the Activity's objectives, its approach, the concept of football as a means of change, and the respective respondents' own roles. Football for Inclusion is selected as an object of observation as it serves as an innovative intervention focusing on the social inclusion of children and youth, arranged in a public-private partnership. In this sense, it represents a form of intervention that is becoming more common in Swedish municipal welfare provision.

In the analysis, the empirical material was interpreted within the framework of the theoretical perspective on problem-solution and conflict-solidarity described previously. Thus, we have interpreted the respondents' statements on Football for Inclusion, and on the potential of football to promote inclusion, as problem statements and constructions of solutions-particularly regarding how problems are described in terms of conflict, and how the proposed solutions are aimed at inclusion and solidarity. Here, the focus of our analysis has been on the technologies of solidarity and on fostering children to equip themselves with the skills deemed necessary for social inclusion. During the process of interpretation, the respondents' statements were divided into problems and solutions. By focusing on how these were interwoven, we were then able to further analyse the understanding of conflict and solidarity, of outside and inside, chaos and order, structuring the discourses about the Area, the families and individuals living there, football and its potential (and meaning) for social change.

\section{Social Inclusion and the Role of Sport}

Previously, Sweden was known for its economic equality and its low levels of poverty. However, in the last decade, segregation and inequalities have rapidly increased in Sweden, creating intensified urban polarisation. In disadvantaged areas throughout Sweden, the interrelated effects of spatial separation, marginalisation in the labour market, and territorial stigmatisation produce social, economic as well as educational inequalities, affecting children and youth in particular (Bunar \& Sernhede, 2013). Together with a sharp increase in immigration to Swe- den in recent years (Dahlstedt \& Neergaard, 2016), these processes of urban polarisation have been manifested in sharper ethno-cultural divisions in the Swedish urban landscape (Gustafsson, Katz, \& Österberg, 2016). More and more, the deprived areas of the urban landscape have been characterised by high levels of migrant populations (Andersson, 2013). For several decades, public debate in Sweden has focused on multi-ethnic suburbs as sites of "otherness", with a continuing focus on the conflicts, deviations, and problems which the areas create in the form of culture clashes, gang rivalry, drugs, poor school performance, and vandalism (Dahlstedt, 2005; Pripp, 2002). In this context, suburban youth is seen as both the source of conflict and the possible solution for creating solidarity (Dahlstedt \& Hertzberg, 2011). Here, sport has been politically assessed as a means of social inclusion (e.g., Government Offices, 2015). In Sweden, expectations of sport practices contributing to social objectives have recently been more explicit (Fahlén \& Stenling, 2016; Norberg, 2011). Sport contributing to social objectives is not a new idea: in the early 1900s, the sports movement was mobilised, with the ideal of diligence and participation, to encourage children and young people to get active, and to highlight sport as a means of developing democratic ideals and creating solidarity by overcoming class conflicts (Norberg, 2011). In this line of thought, practices using sport as an explicit vehicle for promoting social objectives are emerging today in Sweden (Ekholm, 2016), most notably by focusing on social inclusion. Such sports-based interventions are nowadays a common feature globally, targeting youths "at risk" of social exclusion. To mention just a few, the sports-based interventions examined in previous research are: Positive Futures in the UK (Kelly, 2011), the Sport Steward Program in the Netherlands (Spaaij, 2009), DGI Playground in Denmark (Agergaard, Michelsen la Cour, \& Treumer Gregersen, 2015), and the Community Cup in Canada (Rich, Misener, \& Dubeau, 2015).

Research studies on sport for social objectives have noted that such practices could contribute to individual resources such as enhanced self-esteem and selfconfidence (e.g. Fraser-Thomas, Côté, \& Deakin, 2005; Lawson, 2005), as well as contribute to community development and social relations (e.g., Coalter, 2007). At the same time, research spotlights that sport cannot target the fundamental conditions that create segregation and conflict in society (cf. Coakley, 2011; Coalter, 2015; Ekholm, 2016; Hartmann \& Kwauk, 2011). With specific reference to sport as a means of inclusion, some problematic aspects regarding its potential have been identified. It is important to highlight the risk of inclusion in a sports context being seen as synonymous with adaptation (assimilation) to specific norms and to the pre-defined ideals of the majority, creating stereotypes of these groups, maintaining hierarchies, and excluding racialised groups (e.g., Forde, Lee, Mills, \& Frisby, 2015; Hylton, 2011; Long, Hylton, \& Spracklen, 2014; Spaaij et al., 2016). Furthermore, different types of inclusion 
have been identified, involving both the strengthening of bonds within groups, and thereby creating stronger boundaries against other groups (exclusive bonding), as well as the creation of bridging contacts between different groups (inclusive bridging) (Coakley, 2011). The explicit goal of inclusion is usually the latter, i.e., to establish contacts between different groups. At the same time, experiences indicate that at the practical level, inclusion is often a matter of creating cohesion within specific groups (Coakley, 2011). In addition, there is often a strong belief that participating in sports can lead to social mobility (Coakley, 2002, 2011). However, such hopes have often proven to be significantly exaggerated (Hartmann \& Kwauk, 2011; Spaaij, 2009). Using sport to create conditions for social mobility is instead described as quite a naïve dream (Coakley, 2002) which not only conceals the complex causes of the problems and the socioeconomic inequalities that create vulnerability, but can also legitimise the use of sport as a way of controlling children and young people in vulnerable positions (cf. Hartmann \& Kwauk, 2011; Spaaij, 2009).

\section{Analysis}

The following analysis begins with a presentation of the way in which the various problems that are created due to these tensions and conflicts are described by those who are involved in the Activity. The Area and its inhabitants - in terms of families and youth individualsare primarily described on the basis of three recurring discourses: weakness, conflict, and "otherness". The solutions initiated in response to these problems are then presented, with a particular focus on football and its potential for social change based on two main technologies: association-likeness and fostering. Together, these technologies form specific subjects, as well as the arenas where such subjects may be formed, as a means of creating solidarity.

\subsection{Problem: The Problem Area}

The City is described by all respondents as divided. In the description of the divided city, an urban landscape emerges that is divided into diametrically different areas-inside and outside, characterised by order or chaos, normality or otherness, strength or weakness. In this urban landscape, the Area is consistently described as a "weak" place, inhabited by immigrants and the unemployed. In turn, this "weakness" is described as a hotbed for the occurrence of social problems and escalating conflicts. For instance, when describing the aim of the Activity, the Initiator takes a classic philanthropic rationality as a point of departure and emphasises the responsibility of the strong in society to look after the weak:

In the Area, one of the weak areas of the City, the intention is to take care of children from the first, second, and third generation of immigrants, along with children who have parents who do not have an immigrant background, and thus find a better way of creating friendship, mates, understanding of different cultures....You have most of the immigrants in this area. The average income is significantly lower than in the other areas... Unemployment is much more common in these areas....The strong areas are the areas with single-family houses....There, the average income is 20 per cent higher than the average in the City. There, you have children with parents who can help them in school.

In the Initiator's quote, there is a clear line drawn between the strong and the weak areas of the City. The Area is described as weak because the people who live there are immigrants, unemployed, have low incomes, and low levels of education. Thus, a hierarchical relation is constructed between the strong and the weak in the City, in which the strong are in a privileged position but, for that very reason, have a responsibility to "take care of" the weak.

Furthermore, the situation in the Area is described as chaotic. Unless something is done about it, the situation is at risk of deteriorating and posing a threat to solidarity and cohesion in the City as a whole. Thus, among the descriptions, there is a strong undercurrent of risk:

This is what we think we must try to avoid. And there, the aim is to start right from the first class so that the children will not end up in these criminal gangs, but in the world of sports instead, or preferably within the social world, where people integrate with those who come from other areas.

In this description, the emergence of gangs, violence, and criminality constitutes an alarming symptom of a society in chaos and almost in societal collapse, where the conflicts arising in the City's peripheral areas start tearing the social body apart and disrupting its internal forms of solidarity. In this quote, the Initiator tells us that there are already signs that such a negative development is on the way. The account facilitates-and actively proposes-various interventions in order to counteract, and preferably to prevent, such a negative development and chaotic future. In the Initiator's account, the Area is referred to as being characterised by chaos, exclusion, otherness, and weakness, as well as being exposed to serious risks and dangers. The threats portrayed in this scenario are highly destructive. Football, and civil society at large, is presented as an alternative to such a scenario.

\subsection{Problem: Family Problems}

In the stories about the Area's weakness, the weakness is repeatedly related to families, and particularly to parents. In these stories, children, parents, and families of the Area emerge as the bearers of its weakness in the sense that they lack some of the resources, abilities, 
and skills necessary to be able to function in society. In turn, this means that the families and the adolescents run the risk of ending up "excluded", as described by the Headmaster:

It is not the case that these pupils lack knowledge, but they perhaps lack a way of expressing their knowledge, i.e., the Swedish language. And that is the main thing we try and teach them from the start....It is easier to counteract segregation or exclusion if you go about doing so earlier on, of course. The older you are, the tougher it is, partly because of the language to some extent, but also maybe just to keep up in Swedish schools and get the grades required to continue on to higher education and so on. School has already gone by for their parents and it is clear that it will be difficult for them....It is one thing that leads to alienation, of course.

In this quote, the parents are described as being in a position where they find it hard to give the children the support they need to "keep up" at school and to "get the grades required to continue on to higher education". The Swedish language is described as an obstacle for both children and parents, but particularly for those who have come to Sweden at an older age, including the parents, for whom "school has already gone by". On the basis of such a problematisation, there is a hope that the Activity can compensate for the parents' difficulties, particularly by functioning as a place where children can learn Swedish, something that is described as being difficult for them to do in their home environment.

\subsection{Problem: Individuals of Exclusion}

In the interviews, there is a recurring discourse that describes the people living in the Area as part of the problem of exclusion by actively differentiating themselves from the "Swedes". Such differentiation is expressed particularly in relation to the way in which different groups participate in organisations of civil society. One recurring line of argument is that "immigrants", mainly by organising themselves into their "own" associations, are differentiating themselves from "Swedes". Accordingly, "immigrants" are described as establishing associations that strengthen the bonds within their own community, while excluding them from the rest of society.

Here, a particular form of solidarity emerges which differs from the inclusive kind of solidarity that is seen as desirable: one that includes different groups, and transcends the borders between inside and outside (i.e., inclusive bridging, Coakley, 2011). The kind of solidarity taking shape among the groups living in the Area, however, is based on the principle of sameness and community. In this case, the bonds are strengthened primarily within the group (i.e., exclusive bonding, Coakley, 2011). Such inward-looking community-formation is described as further deepening the dynamics of exclusion which then threatens societal solidarity, not just in the City but also in society as a whole. The Initiator is one of those who highlights the dangers of such inward-looking community-formation in the Area:

The young people in that association have a very narrow background. They come from an area in South America [and are part of the Chilean association]. They generally speak Spanish during their training sessions and so on. Or if you take Syrians or...Balkans. This is a big problem in [the City] but also throughout Sweden.

One main problem here is that those living in the Area enclose themselves in "their" own associations. As a consequence, they are gradually disconnected from the surrounding society. In the quote above, language emerges as an important symbol for the rationality of exclusion. With the young people in the Area organising themselves into separate associations where they can-or actually should-speak languages other than Swedish, the boundaries between the inside and the outside are recreated and even strengthened. In this description, the line between the inside and the outside is primarily drawn on ethno-cultural grounds, between Swedishness and otherness.

To summarise the findings so far, the prevalent discourse on the problems identified in the interviews highlights a number of inadequacies of the Area, the individuals (the children), and the families (the children and their parents). These inadequacies are described as a hotbed for the development of a number of tensions, conflicts, and social problems, including crime and the formation of gangs, which pose a threat to solidarity in the City as well as to society as a whole. In this discourse, the Area is described as an area of exclusion where the boundaries are drawn between inside and outside, normality and otherness, strong and weak, and order and chaos. Accordingly, the problems are located in the Area, where individuals as well as the families living there emerge as the source of the problems, the locus of the conflicts, and in need of interventions that will create inclusion and solidarity. In contrast to the Area, the surrounding Swedish society appears as a pre-defined normality.

\subsection{Solution: Association-Likeness}

Within the frames of this particular problematisation, some solutions are made possible and reasonable, while others are put into the background and appear unreasonable or even impossible. On the basis of such discourse, football emerges as a solution to the identified problem of exclusion.

The Activity takes the form of a meeting place for different actors, but it also takes the form of a place where people and different groups in society can meet. This particular meeting place is not an association, and is not organised like a football association in the strict sense of 
the word. Rather, it takes the form of an association-like place, where children and parents can be introduced to the associational way of life in civil society. Participating in football, and thus being introduced to civil society in this particular association-like place, means that children can be fostered in a desirable way.

According to such rationality, Football for Inclusion is portrayed as a bridge between the outside-life in the Area-and the inside-represented by Swedish civil society. Here, participation in civil society, and in this particular form of a sports association, is described as a crucial part of the children's participation in Swedish society as a whole. The primary aim is to "help" and "guide" the children from the outside to the inside. In the words of the Sports leader:

People say that the biggest and best recreation centre is the sports complex. People meet there. There are rules to follow. You have to learn the rules. It's good to be busy. If you have recreation centres where you are close to one another, where people can meet...otherwise you might do other things that are not as good.

The recreation centre metaphor is telling as it explicitly describes the Activity as a pedagogic arena in which the participants are fostered in specific ways and according to specific norms. In this arena, the boundaries and tensions of society can be overcome by fostering and diversion. So what is it, then, that the children who are to be fostered will gain by participating in football?

\subsection{Solution: Fostering}

First and foremost, there are three objectives of fostering that recur in the interviews: fostering for friendship, for diligence, and for adaptation. In all the stories a specific citizen-subject appears. The different fostering technologies initiated under the auspices of football are facilitated by the specific discourse on the problems outlined above. On the basis of this discourse, the children are seen as being in need of fostering to become part of and to embrace the rules and norms of the societal community.

In the interviews, the metaphor of the game functions as a way of understanding how society and life in general work, and thereby also the way in which fostering ought to take place. In this game, the children acquire the skills deemed important for inclusion. Here, a strong focus is put on the importance of fostering team players. As the Organiser points out, this is why friendship and the capacity to cooperate are emphasised as important guiding principles in the Activity.

It is arranged in a slightly different way from the traditional association sport...the guiding principles are ball games, football games and enjoyment of exercise. Maybe some technique. It must be friendship and collaboration which drive everything.
In order to become a good team player, children need to conform to the rules of the game. Here, the norm of friendship is strongly related to the norm of diligence: to behave. Football offers a clear pedagogic rationale: it is a game played out on a playing field with a set of rules. It lasts for a specific time, but it can also be called off. Sports coach 1 describes how calling it off is a technique of teaching the children how to behave:

Sometimes a palaver has arisen, full on. That is when we have stopped the game and made everyone go and sit down. Then we have sat and talked-about how to behave, about how you should behave towards others and stuff like that. You either behave or have to sit and talk [laughs]. We've stopped a fair few times and just sat and talked about how to behave, what to do, what it is to be part of a team and stuff like that.

The game has clear rules. There is no space for compromise. The rules are to be followed. Accordingly, the children are taught to become diligent. Social abilities are an important part of the rules of the game, i.e. the capacity to be part of a broader social context, to cooperate with others and, not least, cooperate with others who are different. As the Sports leader summarises it:

Rules and types of work...it's very good for there are certain rules you have to abide by....The aim is to develop their social and linguistic skills....We assess swearing and things like that by stopping the game and discussing with them. The social aspect is important. They're forced to cooperate with one another and mix.

Mixing is the key, as fostering aims at breaking the introspection among the children and replacing it with extrospection (outward observation) towards the surrounding society, its expectations, norms, and values. Here, the norm of diligence relates to another norm, that of adaptation. The Initiator explicitly talks in terms of adaptation when he describes the prospects of the Activity:

If you do not take them in hand in the world of football, gangs will form....The idea is to find a social way of trying to prevent that. If you lower the ages you deal with, the idea is to see whether you can avoid problems in this area, everything from graffiti to destruction and the theft of bicycles..... It would be wonderful if it were also possible to get them to better adapt to Swedish society and have more success at school.

Success requires early interventions and this is exactly why participation in football can be seen as a potential means of progress. Under the auspices of football, opportunities are offered to encourage children to adapt to Swedish society. In the interviews, for example with the Organiser, the rules of the game are regularly related to specific values, defined in terms of Swedish-ness: 
So, this activity is a method of integrating and functioning in a good way. There are some Swedish traditions when it comes to organisation and rules, yes...how you behave.

Here, encouraging diligence is synonymous with "Swedish traditions". Thus, fostering becomes an adaptation to Swedish-ness. The important pedagogic challenge is how to develop a desire among the children to integrate, to develop a will to move from the outside, and to adapt to the order of the inside.

Thus, with sport as a means, a range of technologies of fostering and solidarity are initiated, making the Area, its children and the parents, reachable and includable. These technologies are facilitated by collaboration between a number of actors; collaboration that is based on community and solidarity through the creation of an association-like arena in which an appropriate and normal way of living can be fostered and can take shape. In the Activity, these technologies of fostering solidarityin relation to the boundaries, tensions, and potential conflicts that threaten solidarity-may be arranged and put into use.

\section{Conclusion}

The problems identified among those involved in the Activity consist of frictions and conflicts created by segregation, and by the boundaries between those who are on the inside and those who are on the outside. Here, football is presented as a productive means of creating solidarity. Boundaries are drawn between inside and outside, normal and foreign, strong and weak, and order and chaos. The problems and conflicts in the City are essentially located in the Area, and the inhabitants are portrayed as the source of the problems and the causes of the conflicts.

The technologies that target the children also reach out to the parents, involving and stimulating them to want to become a part of society as insiders. By the creation of an inclusive arena where something referred to as specifically Swedish is arranged, like an association, people who are excluded can have the opportunity to learn and adapt to the values and abilities described as crucial in order to become part of Swedish society. Thus, Football for Inclusion appears to be a way in which the welfare state can reach out to the Area, with the ambition of incorporating those on the "outside" into the "inside" by changing their conduct. This is crucial in order to understand the kind of solidarity created, which is different compared with the kind of solidarity outlined previously in the article. This form of intervention differs from the normalising measures described regarding the lines of conflict that are to be overcome and the kind of solidarity that is to be created. The historical lines of conflict, to which solidarity was a solution, were based on socioeconomic divisions - the class struggle or individual competition. The objective of the kind of solidarity contem- plated was to even out and compensate for unequal living conditions through social interventions-to dissolve socio-economic divisions and stifle class conflict by creating a cohesive social collective and a sense of solidarity.

In this sports-based intervention, there are different lines of conflict appearing as well as a different way of dealing with these conflicts. Firstly, the lines of conflict are interpreted primarily along socio-cultural lines. The excluded-the foreign, weak, and disordered-are described as ethno-culturally different from Swedish society. Here, the division is drawn between the inside and the outside, where the outsiders are defined in terms of "ethno-cultural otherness". Secondly, the technologies of solidarity that are facilitated are primarily based on maintaining the division between inside and outside. The aim is not to dissolve this division, but rather to recognise it. The ambition is to equip individuals and families on the outside with the ability to cross the border and enter the inside. For those picking up the "right" values and adapting to the dominant concepts of inclusion, the path to inclusion appears as a journey in an already established landscape. Instead of the division between inside and outside being dissolved, it is maintained, but at the same time it is overcome by the individuals and the families in the Area adapting to the normality of the inside (Swedish-ness). Here, adaptation to the norms and behaviours of the "inside" emerge as a dominant technology of solidarity. The divisions in the social body are not to be dissolved, but rather to be maintained, yet at the same time to be overcome by adaptation. The emphasis on the individualisation of social problems and the adaptation to current norms has been an ever-present issue, widely dealt with in research on social work and social policy interventions (i.e., Parton, 1996; Webb, 2006). Particularly, individualisation and adaptation are recurring concerns in the research into sports-based interventions, in the Swedish (Ekholm, 2017b) as well as in a range of other welfare states (i.e., Kelly, 2011; Rich et al., 2015).

The Football for Inclusion sports-based intervention sets out to deal with conflicts without comprehensive reform or questioning boundaries. It is the Area, the families and the individuals who, as it were, end up on the wrong side of the boundaries-and who thereby represent the lack of and the problem of solidarity-who are attributed the position of "excluded" and who are problematised and made subjects of social change. Such an approach to conflicts and to establishing order rather than reform raises questions about the welfare state's focus on the rationality of solidarity. On the basis of the intervention on which we have focused in this article, it may be possible to discuss the contours of a greater reconstitution of social policy: of how the welfare state deals with social problems, not only in Sweden but in other countries as well, i.e., by maintaining boundaries and order in combination with pedagogics for adaptation and cultural normalisation. Addressing such questions is important for further research and has implications for both policy and practice. 


\section{Acknowledgements}

The article is based on research conducted by the support of the Swedish Research Council for Sport Science. The authors want to thank Caroline Ellefsen Hansen, Alexander Sparr and Elin Törnros for their contributions in the data collection.

\section{Conflict of Interests}

The authors declare no conflict of interests.

\section{References}

Agergaard, S., Michelsen la Cour, A., \& Treumer Gregersen, M. (2015). Politicisation of migrant leisure: A public and civil intervention involving organised sport. Leisure Studies, 35(2), 200-214.

Andersson, R. (2013). Reproducing and reshaping residential segregation in Stockholm. Geografiska annaler: Series B, Human Geography, 95(2), 163-187.

Bacchi, C. (2009). Analysing policy: What's the problem represented to be? Frenchs Forest: Pearson.

Bunar, N., \& Sernhede, O. (Eds.). (2013). Skolan och ojämlikhetens urbana geografi. Gothenburg: Daidalos.

Coakley, J. (2002). Using sports to control deviance and violence among youths: Let's be critical and cautious. In M. Gatz, M. A. Messner, \& S. J. Ball-Rokeach (Eds.), Paradoxes of youth and sport (pp. 13-30). Albany: State University of New York Press.

Coakley, J. (2011). Youth sports: What counts as "positive development". Journal of Sport and Social Issues, 35(3), 306-324.

Coalter, F. (2007). A wider social role for sport: Who's keeping the score? London: Routledge.

Coalter, F. (2015). Sport-for-change: Some thoughts from a sceptic. Social Inclusion, 3(3), 19-23.

Dahlstedt, M. (2005). Reserverad demokrati. Umeå: Boréa.

Dahlstedt, M., \& Hertzberg, F. (2011). Skola i samverkan. Malmö: Gleerups.

Dahlstedt, M., \& Neergaard, A. (2016). Crisis of solidarity? Changing welfare and migration regimes in Sweden. Critical Sociology. doi:10.1177/ 0896920516675204

Donzelot, J. (1979). The policing of families. London: The John Hopkins University Press.

Donzelot, J. (1988). The promotion of the social. Economy and Society, 17(3), 395-427.

Donzelot, J. (1991). The mobilization of society. In G. Burchell, C. Gordon, \& P. Miller (Eds.), The Foucault effect: Studies in governmentality (pp. 169180). Chicago: University of Chicago Press.

Ekholm, D. (2016). Sport as a means of responding to social problems: Rationales of government, welfare and social change (PhD dissertation). Department of Social and Welfare Studies, Linköping University.

Ekholm, D. (2017a). Mobilising the sport-based community: The construction of social work through ratio- nales of advanced liberalism. Nordic Social Work Research. doi:10.1080/2156857X.2017.1310127

Ekholm, D. (2017b). Sport-based risk management: Shaping motivated, responsible and self-governing citizen subjects. European Journal for Sport and Society, 14(1), 60-78.

Esping-Andersen, G. (1990). Three worlds of welfare capitalism. Cambridge: Polity Press.

Fahlén, J., \& Stenling, C. (2016). Sport policy in Sweden. International Journal of Sport Policy and Politics, 8, 1-17.

Forde, S. D., Lee, D. S., Mills, C., \& Frisby, W. (2015). Moving towards social inclusion: Manager and staff perspectives on an award winning community sport and recreation program for immigrants. Sport Management Review, 18, 126-138.

Foucault, M. (2004). Polemics, politics, and problematizations. In P. Rabinow (Ed.), The Foucault reader (pp. 380-391). London: Penguin Books.

Fraser-Thomas, J., Côté, J., \& Deakin, J. (2005). Youth sport programs: An avenue to foster positive youth development. Physical Education and Sport Pedagogy, 10(1), 19-40.

Government Offices. (2015). Ökat anslag till idrottsrörelsen i kommande vårproposition. Press release, 14 April 2015.

Gustafsson, B., Katz, K., \& Österberg, T. (2016). Residential segregation from generation to generation: Intergenerational association in socio-spatial context among visible minorities and the majority population in metropolitan Sweden. Population, Space and Place. doi:10.1002/psp.2028

Hartmann, D., \& Kwauk, C. (2011). Sport and development: An overview, critique, and reconstruction. Journal of Sport and Social Issues, 35(3), 284-305.

Hylton, K. (2011). Sport and social integration. In B. Houlihan, \& M. Green (Eds.), Routledge handbook of sports development (pp. 100-113). London: Routledge.

Kelly, L. (2011). "Social inclusion" through sports-based interventions? Critical Social Policy, 31(1), 126-150.

Larsson, B., Letell, M., \& Thörn, H. (2012). Transformations of the Swedish welfare state: Social engineering, governance and governmentality: An introduction. In B. Larsson, M. Letell, \& H. Thörn (Eds.), Transformations of the Swedish welfare state (pp. 3-22). New York: Palgrave MacMillan.

Lawson, H. A. (2005). Empowering people, facilitating community development, and contributing to sustainable development: The social work of sport, exercise and physical education programs. Sport, Education and Society, 10(1), 135-160.

Long, J., Hylton, K., \& Spracklen, K. (2014). Whiteness, blackness and settlement: Leisure and integration of new migrants. Journal of Ethnic and Migration Studies, 40(11), 1779-1797.

Norberg, J. R. (2011). A contract reconsidered? Changes in the Swedish state's relation to the sports move- 
ment. International Journal of Sport Policy and Politics, 3, 311-325.

Parton, N. (Ed.). (1996). Social theory, social change and social work. London: Routledge.

Philp, M. (1979). Notes on the form of knowledge in social work. The Sociological Review, 27(1), 83-111.

Pripp, O. (2002). Mediabilder och levd erfarenhet. In I. Ramberg \& O. Pripp (Eds.), Fittja, världen och vardagen (pp. 41-72). Botkyrka: Mångkulturellt centrum.

Rich, K., Misener, L., \& Dubeau, D. (2015). “Community Cup, we are a big family": Examining social inclusion and acculturation of newcomers to Canada through a participatory sport event. Social Inclusion, 3(3), 129-141.

\section{About the Authors}

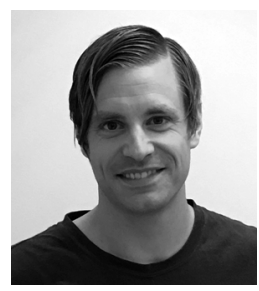

David Ekholm is a researcher and lecturer at Linköping University. Ekholm's main research interests are in the sociology of social work and social policy in relation to contemporary welfare state transformations. Here, he has a particular focus on youth interventions aiming for social inclusion. Ekholm's research are characterised by a variety of constructionist and critical approaches.

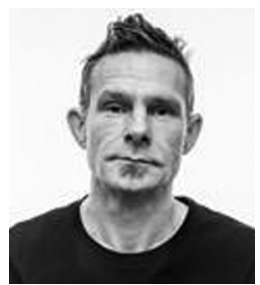

Magnus Dahlstedt is Professor in Social Work at Linköping University. Dahlstedt's main research interests are the politics of inclusion/exclusion, citizenship and democracy. Currently, his research is mainly oriented towards the formation of citizenship in the context of the multi-ethnic city. Dahlstedt has published several books, among others The Confessing Society: Foucault, Confession and Practices of Lifelong Learning, co-authored with Andreas Fejes (Routledge, 2013), and International Migration and Ethnic Relations: Critical Perspectives, co-edited with Anders Neergaard (Routledge, 2015). 